\title{
ENERGY BALANCE METHODOLOGY AND MODELING OF SUPPLEMENTARY FORAGE PRODUCTION FOR CATTLE IN BRAZIL
}

\author{
Thiago Libório Romanelli ${ }^{1}$; Marcos Milan²* \\ ${ }^{I}$ USP/ESALQ - Programa de Pós-Graduação em Máquinas Agrícolas. \\ ${ }^{2}$ USP/ESALQ - Depto. de Engenharia Rural, C.P. 9 - 13418-900 - Piracicaba, SP - Brasil \\ *Corresponding author <macmilan@esalq.usp.br>
}

\begin{abstract}
Cattle is the main protein source in Brazil and cattle production depends on preserving forage in order to decrease the influence of dry periods on grass production. To minimize such problems, some new techniques have been created to increase the yield which also leads to energy demand increase. Energy balance is a vital tool to evaluate the efficiency of energy consumption in production systems. There is no standard methodology established for this determination. It is also difficult to analyze different management options because of the complexity of the production systems and the interactions among variables. Therefore the purpose of this study is to develop a methodology that supports the development of a model, using a spreadsheet, and to use it to analyze the energy balance of production systems. The model was applied to a traditional production system of maize (Zea mays L.) silage and a Bermuda grass (Cynodon spp.) haylage. The gross energy balance presented was 14.1 energy units of output per energy units of input for maize silage and -0.98 for haylage. For the digestible energy balance, the values were 9.1 and -0.99 , respectively. The total energy demanded was $74.3 \%$ in maize silage fertilizations and $99.7 \%$ in haylage irrigation. Yield and dry matter contents were indicated in a sensitivity analysis as the main critical variables for maize, whereas for haylage, it was not possible to indicate any. The best alternative scenarios for improving energy efficiency in maize silage and haylage production were the reductions of fertilizer concentration and irrigation use, respectively.

Key words: environmental management, production systems, sustainability, silage, haylage
\end{abstract}

\section{METODOLOGIA E MODELAGEM DO BALANÇO ENERGÉTICO EM FORRAGENS SUPLEMENTARES PARA BOVINOS}

\begin{abstract}
RESUMO: A pecuária é a principal fonte de proteína no Brasil, e sofre pela estacionalidade das chuvas, necessitando-se da suplementação alimentar. Para amenizar tais problemas surgem técnicas visando o aumento da produtividade, porém demandando mais energia. O balanço energético é uma importante ferramenta para avaliar a eficiência com que um sistema de produção utiliza os insumos, pois relaciona os fluxos de energia de entrada (input) e a energia disponibilizada pelo sistema (output). No entanto, não há uma metodologia padrão para tal análise, e ainda analisar diferentes opções não é uma tarefa fácil, pela complexidade de sistemas agrícolas e pelas interações de suas variáveis. Sendo assim, o presente trabalho objetivou propor uma metodologia de determinação do balanço energético, que desse suporte ao desenvolvimento de um modelo em planilha eletrônica. Este foi utilizado para avaliar dois sistemas: um de produção de silagem de milho (Zea mays L.) e um de silagem emurchecida de Tifton 85 (Cynodon spp.). A silagem de milho apresentou balanços energéticos bruto de 14,08 e a emurchecida $-0,98$, já para o balanço de energia digestível foram $9,12 \mathrm{e}-0,99$, respectivamente. As adubações demandaram $73,4 \%$ do total de energia na silagem de milho e a irrigação 99,7\% na emurchecida. A análise de sensibilidade indicou produtividade e teor de matéria seca como variáveis críticas do balanço energético para a silagem de milho. Na emurchecida tal análise não indicou variável alguma. Reduções da concentração do fertilizante e uso de irrigação foram as melhores alternativas para o milho e o Tifton 85 , respectivamente.
\end{abstract}

Palavras-chave: gestão ambiental, sistemas de produção, sustentabilidade, silagem, silagem emurchecida

\section{INTRODUCTION}

Food production has been one of the main problems of humankind. According to FNP Consultoria e Comercio (2000), Brazil is considered the second largest country in cattle meat production. Due to the economic importance of cattle raising, there is a great concern about the supplementary forage needed to feed the herd during the dry seasons, when pasture availability and quality are reduced. To assure feed production, innovations have 
been developed to produce higher yields but these demand higher levels of energy inputs (Ulbanere \& Ferreira, 1989). As a result of this increase, production costs increased as well as energy consumption (Ferraro Jr., 1999). Therefore, a long-term sustainability of production systems is threatened (Stanhill, 1984).

The energy balance is an important tool to determine the efficiency of the use of an agricultural system, quantifying input and output flows (Hetz, 1992). Besides some energy balances determined for maize silage, there are no established methodologies for this analysis. For instance, Pimentel (1984) presented the quantity for each input applied per hectare and its relative energy content per hectare in production systems in the USA. Campos et al. (1998) calculated the energy contents of inputs and their total consumption per hectare of maize silage considering the average data of 14 crops grown in Brazil during seven years.

Phipps et al. (1976) presented data about human labor and fuel required per hectare of each mechanized operation to establish and harvest maize silage. For a conventional crop, fertilizers are responsible for $59 \%$ and fuel for $16 \%$ of the total energy demand, respectively. There is a $10 \%$ reduction of the total energy demand when direct drilling is adopted. The most efficient method for reducing energy is using slurry as fertilizer. No energy enclosed in the slurry was considered but some authors suggest that it can be determined through chemical elements contained in organic fertilizers.

Hetz (1992) determined a range of maize silage energy balances, considering all the inputs applied in the production systems, such as: human labor, machinery, seed, fertilizers, fuels, lubricants, irrigation, biocides and others. It was concluded that larger farmers (>10 ha) tend to use more energy and fuels, and $\mathrm{N}$ and $\mathrm{P}$ fertilizers are responsible for most of the energy demand representing $80 \%$ of the total. According to the author, natural fertility, the use of natural nitrate as the $\mathrm{N}$ source, the high rate of photosynthesis, the use of gravitational irrigation, more human labor and animal traction are the main factors for the higher values obtained.

Phipps et al. (1976), Pimentel (1984), Hetz (1992) and Campos et al. (1998) showed the averages of production systems surveyed by them but they did not describe the methodology used to compute these data. Although fertilizers and fuel are indicated as being the main energy demanding inputs, critical variables were not indicated to measure how they influence the energy balance.

It is difficult to analyze different scenarios of any agricultural production system taking into consideration the amount of variables involved and the complexity of their interactions. This is where modeling is useful. In order to evaluate different production systems regarding their sustainability risks, the purpose of this work was to present a method and develop a model to evaluate the energy demand of forage production systems.

\section{MATERIAL AND METHODS}

This work was first conducted by the methodology of energy balance determination. This first step gave support for the development of an algorithm in order to determine the energy balance of supplementary forage production systems. The methodology proposed that gives support to the model is presented in equations 1 to 16 . The energy balance is calculated using the net energy provided by the production system according to Equation 1 .

$\mathrm{EB}_{\mathrm{G}}=\frac{\mathrm{OEG}_{\mathrm{G}}-\mathrm{IE}}{\mathrm{IE}}$

where: $\mathrm{EB}_{\mathrm{G}}=$ gross energy balance (non dimensional); $\mathrm{OE}_{\mathrm{G}}=$ gross output energy $\left(\mathrm{MJ} \mathrm{ha}^{-1}\right) ; \mathrm{IE}=$ input energy $\left(\mathrm{MJ} \mathrm{ha}^{-1}\right)$.

In Equation 2, the digestible energy balance $\left(\mathrm{EB}_{\mathrm{D}}\right)$, which considers the Total digestible nutrients (TDN) level, is determined indicating the effective energy provided to the cattle.

$\mathrm{EB}_{\mathrm{D}}=\frac{\mathrm{OED}-\mathrm{IE}}{\mathrm{IE}}$

where: $\mathrm{OE}_{\mathrm{D}}=$ digestible output energy $\left(\mathrm{MJ} \mathrm{ha}^{-1}\right)$.

With the goal of comparing different production systems, the daily gross energy balance $\left(\mathrm{EB}_{\mathrm{GD}}\right)$, regarding soil occupation on the energetic efficiency of the systems, was determined as shown in Equation 3. The daily digestible energy balance $\left(\mathrm{EB}_{\mathrm{DD}}\right)$ is calculated according to Equation 4.

$\mathrm{EB}_{\mathrm{GD}}=\frac{\mathrm{EBG}_{\mathrm{G}}}{\mathrm{SO}}$
$\mathrm{EB}_{\mathrm{DD}}=\frac{\mathrm{EBD}}{\mathrm{SO}}$

where: $\mathrm{EB}_{\mathrm{GD}}=$ daily gross energy balance $\left(\right.$ days $\left.^{-1}\right) ; \mathrm{EB}_{\mathrm{DD}}$ $=$ daily digestible energy balance $\left(\right.$ days $\left.^{-1}\right) ; \mathrm{SO}=$ days the crop occupies the soil.

\section{Input energy calculation}

The input energy was determined according to:

$\mathrm{IE}=\mathrm{E}_{\mathrm{I}}+\mathrm{E}_{\mathrm{ED}}+\mathrm{E}_{\mathrm{F}}+\mathrm{E}_{\mathrm{L}}+\mathrm{E}_{\mathrm{IR}}$

where: $\mathrm{E}_{\mathrm{I}}=$ energy to produce applied inputs $\left(\mathrm{MJ} \mathrm{ha}^{-1}\right)$; $\mathrm{E}_{\mathrm{ED}}=$ energy expended in machinery manufacture, depreciated over their useful life $\left(\mathrm{MJ} \mathrm{ha}^{-1}\right)$; $\mathrm{E}_{\mathrm{F}}=$ energy in the fuel consumed by machinery $\left(\mathrm{MJ} \mathrm{ha}^{-1}\right) ; \mathrm{E}_{\mathrm{L}}=$ energy consumed by the applied human labor $\left(\mathrm{MJ} \mathrm{ha}^{-1}\right) ; \mathrm{E}_{\mathrm{IR}}=$ energy used in irrigation $\left(\mathrm{MJ} \mathrm{ha}^{-1}\right)$. 
a) Energy of applied inputs $\left(\mathrm{E}_{\mathrm{I}}\right)$ - The applied inputs were divided in two categories: solid and liquid. The solid inputs are limestone, seeds and fertilizers and the liquid inputs are the pesticides utilized on crops. The energy of applied input is determined according to:

$\mathrm{E}_{\mathrm{I}}=\mathrm{E}_{\mathrm{si}}+\mathrm{E}_{\mathrm{li}}$

where: $\mathrm{E}_{\mathrm{si}}=$ enclosed energy in solid inputs applied in the production systems $\left(\mathrm{MJ} \mathrm{ha}^{-1}\right) ; \mathrm{E}_{\mathrm{li}}=$ enclosed energy on applied pesticides $\left(\mathrm{MJ} \mathrm{ha}^{-1}\right)$.

a.1) Solid inputs - The determination of the demanded energy of these inputs depends on the application rate and the enclosed energy of each. This enclosed energy can be obtained as shown by:

$\mathrm{E}_{\mathrm{si}}=\mathrm{Qt}$ Eci

where: Qt = quantity of input applied per hectare $\left(\mathrm{kg} \mathrm{ha}^{-1}\right) ; \mathrm{Eci}=$ energy content of a solid input $\left(\mathrm{MJ} \mathrm{kg}^{-1}\right)$. Energy indexes can be found on the Tables 1 to 3 .

a.2) Liquid inputs - Their energy content $\left(\mathrm{E}_{\mathrm{li}}\right)$ is determined as shown in Equation 8:

$\mathrm{E}_{\mathrm{li}}=\frac{(\text { Eli) (i.a.) }(\mathrm{Vp})}{\mathrm{Va}} \mathrm{Q}$

Table 1 - Energy indexes of seeds.

\begin{tabular}{lcl}
\hline Seed & MJ kg-1 $^{-1}$ & \multicolumn{1}{c}{ Reference } \\
\hline Maize & 15.45 & Pimentel (1980) \\
Cereals and forages & 10.50 & Pellizzi (1992) \\
\hline
\end{tabular}

Table 2 - Energy indexes of fertilizers.

\begin{tabular}{lrl}
\hline Fertilizer & $\mathrm{MJ} \mathrm{kg}^{-1}$ & Reference \\
\hline $\mathrm{N}$ & 74.00 & Pellizzi (1992) \\
\hline Urea & 78.04 & Ferraro Jr. (1999) \\
Anhydrous ammonia & 68.03 & Ferraro Jr. (1999) \\
\hline Ammonium Nitrate & 77.03 & Ferraro Jr. (1999) \\
Ammonium Sulfate & 21.98 & Ferraro Jr. (1999) \\
Potassium Nitrate & 14.65 & Ferraro Jr. (1999) \\
Calcium Nitrate & 16.74 & Ferraro Jr. (1999) \\
\hline $\mathrm{P}_{2} \mathrm{O}_{5}$ & 12.56 & Ferraro Jr. (1999) \\
Simple Phosphate & 9.79 & Ferraro Jr. (1999) \\
Triple Phosphate & 22.11 & Ferraro Jr. (1999) \\
Termo phosphate & 3.77 & Ferraro Jr. (1999) \\
Natural Phosphate & 0.63 & Ferraro Jr. (1999) \\
Diammonium Phosphate & 44.09 & Hetz (1992) \\
\hline K ${ }_{2} \mathrm{O}$ & 6.70 & Ferraro Jr. (1999) \\
KCl & 7.19 & Ferraro Jr. (1999) \\
\hline Potassium Sulphate & 3.35 & Ferraro Jr. (1999) \\
Limestone & 1.67 & Ferraro Jr. (1999) \\
\hline
\end{tabular}

Sci. Agric. (Piracicaba, Braz.), v.62, n.1, p.1-7, Jan./Feb. 2005 where: Eli = enclosed energy of a liquid input $\left(\mathrm{MJ} \mathrm{L}^{-1}\right)$; i.a. = concentration of the active ingredient in the commercial product $(\%) ; \mathrm{Vp}=$ used volume of the commercial product $(\mathrm{L}) ; \mathrm{Va}=$ volume to be applied $(\mathrm{L}) ; \mathrm{Q}=$ application rate $\left(\mathrm{L} \mathrm{ha}^{-1}\right)$.

b) Energetic depreciation $\left(\mathrm{E}_{\mathrm{ED}}\right)$ - The total energy consumed through energetic depreciation is calculated according to:

$\mathrm{E}_{\mathrm{ED}}=\mathrm{D}_{\mathrm{MM}}+\mathrm{D}_{\mathrm{PM}}+\mathrm{D}_{\mathrm{IR}}$

where: $\mathrm{D}_{\mathrm{MM}}=$ energy consumed by the energetic depreciation of tractors and self-propelled machinery $\left(\mathrm{MJ} \mathrm{ha}^{-1}\right)$; $\mathrm{D}_{\mathrm{PM}}=$ energy consumed by the energetic depreciation of pulled machines and implements $\left(\mathrm{MJ} \mathrm{ha}^{-1}\right) ; \mathrm{D}_{\mathrm{IR}}=$ energy consumed by the energetic depreciation of irrigation systems $\left(\mathrm{MJ} \mathrm{ha}^{-1}\right)$.

b.1) Machinery - The manufacture of motorized machinery presents a specific demand of energy of 68.9 $\mathrm{MJ} \mathrm{kg}^{-1}$, named in this work as SDEm, while pulled machinery $\left(\mathrm{SDE} p\right.$ ) is $57.2 \mathrm{MJ} \mathrm{kg}^{-1}$ (Ulbanere \& Ferreira, 1989). The $D_{M M}$ and $D_{P M}$ of machinery are calculated according to:

$\mathrm{D}_{\mathrm{MM} / \mathrm{PM}}=\frac{\mathrm{M} \mathrm{SDE} m / p}{\mathrm{Oc} \mathrm{UL}}$

where: $\mathrm{M}=$ mass $(\mathrm{kg}) ; \mathrm{SDE} m=$ specific demand of energy of motorized machinery $\left(\mathrm{MJ} \mathrm{kg}^{-1}\right) ; \mathrm{SDE} p=$ specific demand of energy for pulled machinery $\left(\mathrm{MJ} \mathrm{kg}^{-1}\right) ; \mathrm{Oc}=$ operational work capacity $\left(\mathrm{ha} \mathrm{h}^{-1}\right)$; UL $=$ useful life of the equipment (h).

b.2) Irrigation systems - The energetic depreciation of irrigation systems $\left(D_{I R}\right)$ is calculated according to:

Table 3 - Energy indexes of some pesticides.

\begin{tabular}{lrl}
\hline Pesticides & MJ kg-1 $^{-1}$ & \multicolumn{1}{c}{ Reference } \\
\hline Herbicide & 254.57 & Pimentel (1980) \\
Insecticide & 184.71 & Pimentel (1980) \\
Fungicide & 97.13 & Pimentel (1980) \\
Diuron & 274.62 & Fluck \& Baird (1982) \\
Atrazina & 188.38 & Fluck \& Baird (1982) \\
Trifluralina & 150.97 & Fluck \& Baird (1982) \\
Paraquat & 459.60 & Fluck \& Baird (1982) \\
\hline 2.4 - D & 87.04 & Fluck \& Baird (1982) \\
2.4.5 - T & 135.06 & Fluck \& Baird (1982) \\
Dicamba & 295.13 & Fluck \& Baird (1982) \\
Glifosate & 454.20 & Fluck \& Baird (1982) \\
Diquat & 400.18 & Fluck \& Baird (1982) \\
Captan & 115.05 & Fluck \& Baird (1982) \\
\hline Carbofuran & 454.20 & Fluck \& Baird (1982) \\
\hline
\end{tabular}


$\mathrm{D}_{\mathrm{IR}}=\frac{\mathrm{M} \mathrm{SDE} \mathrm{Ud} \mathrm{ND}}{\mathrm{UL} \mathrm{Ai}}$

where: $\mathrm{SDE}=$ specific demand of energy $\left(\mathrm{MJ} \mathrm{kg}^{-1}\right) ; \mathrm{Ud}$ $=$ daily average use $(\mathrm{h}) ; \mathrm{ND}=$ period of irrigation during the cycle (days); UL = useful life (h); $\mathrm{Ai}=$ total irrigated area by the system (ha).

c) Fuel energy $\left(\mathrm{E}_{\mathrm{F}}\right)$ - The applied energy through fuel consumption $\left(\mathrm{E}_{\mathrm{F}}\right)$ is determined by Equation 12 .

$E_{F}=\frac{F c \text { fc }}{O c}$

where: $\mathrm{Fc}=$ fuel consumption per hour $\left(\mathrm{L} \mathrm{h}^{-1}\right) ; \mathrm{fc}=$ factor of enclosed energy in fuels, 38.6 $\mathrm{MJ} \mathrm{L}^{-1}$ for diesel oil (Ulbanere \& Ferreira, 1988).

d) Human labor $\left(\mathrm{E}_{\mathrm{L}}\right)$ - According to Serra et al. (1979), one man demands $2.2 \mathrm{MJ}$ per worked hour, so the determination of the energy consumed by the applied human labor $\left(\mathrm{E}_{\mathrm{L}}\right)$ is given by:

$E_{L}=\frac{W H f_{L}}{A w}$

where: $\mathrm{WH}=$ total worked hours (h man); $\mathrm{f}_{\mathrm{L}}=$ factor of consumed energy per hour of human labor $\left(\mathrm{MJ} \mathrm{h}^{-1} \mathrm{man}^{-1}\right)$; Aw $=$ worked area (ha).

e) Irrigation $\left(E_{I R}\right)$ - The energy consumption for the irrigation system to work is calculated according to:

$\mathrm{E}_{\mathrm{IR}}=\frac{\text { fee Pe Ud ND }}{\mathrm{Ai}}$

where: $\mathrm{f}_{\mathrm{ee}}=$ enclosed energy in electrical energy, $12.0 \mathrm{MJ}$ $\mathrm{kW}^{-1} \mathrm{~h}^{-1}$ (Pimentel, 1984); Pe = power of the motor driving the pumping system $(\mathrm{kW}) ; \mathrm{Ud}=$ average daily use (h).

\section{Output energy calculation}

Equation 15 was utilized to determine gross output energy $\left(\mathrm{OS}_{\mathrm{G}}\right)$.

$\mathrm{OE}_{\mathrm{G}}=\left(\mathrm{Y} \frac{\mathrm{DM}}{100}\right)\left\{\left(\frac{\mathrm{CP}}{100} \mathrm{f}_{\mathrm{CP}}\right)+\left(\frac{\mathrm{EE}}{100} \mathrm{f}_{\mathrm{EE}}\right)+\left(\frac{\mathrm{CF}}{100} \mathrm{f}_{\mathrm{CF}}\right)+\right.$

$\left.\left(\frac{\mathrm{NFE}}{100} \mathrm{f}_{\mathrm{NFE}}\right)\right\}$

where: $\mathrm{Y}=$ yield $\left(\mathrm{kg} \mathrm{ha}^{-1}\right) ; \mathrm{DM}=$ dry matter $(\%) ; \mathrm{CP}=$ crude protein content $(\%) ; \mathrm{f}_{\mathrm{CP}}=$ crude protein enclosed energy (24.4 $\left.\mathrm{MJ} \mathrm{kg}^{-1}\right)$; $\mathrm{EE}=$ ether extract content (\%); $\mathrm{f}_{\mathrm{EX}}=$ ether extract enclosed energy $\left(38.9 \mathrm{MJ} \mathrm{kg}^{-1}\right) ; \mathrm{FB}=$ crude fiber content $(\%) ; \mathrm{f}_{\mathrm{CF}}=$ crude fiber enclosed energy $\left(18.0 \mathrm{MJ} \mathrm{kg}^{-1}\right) ; \mathrm{NFE}=$ nitrogen free extract content $(\%) ; \mathrm{f}_{\mathrm{NFE}}=$ nitrogen free extract enclosed energy $(18.0$
MJ kg $\left.{ }^{-1}\right)$. All of the enclosed energies presented at Equation 15 were used by Crampton \& Harris (1956).

Equation 16 was used to determine digestible output energy $\left(\mathrm{OE}_{\mathrm{D}}\right)$. The efficiency of providing energy to cattle through supplementary forage is implicit.

$\mathrm{OE}_{\mathrm{D}}=\mathrm{OE}_{\mathrm{B}} \frac{\mathrm{TDN}}{100}$

where: $\mathrm{TDN}=$ total digestible nutrients $(\%)$.

The model algorithm was implemented in an electronic spreadsheet program, which was verified to check possible errors and validated through comparison of data obtained from references. Field determinations were conducted to determine required data for the model considering the mechanized systems: work speed, fuel consumption, effective work width and input application rate. Materials to be ensiled were submitted to bromatological analysis, for the quantification of some compounds, which were necessary to determine gross output energy $\left(\mathrm{OE}_{\mathrm{G}}\right)$. The flow chart of the general algorithm, based on the production systems, is shown in Figure 1.

To run model (box 1 of Figure 1), the user provides the data regarding the production system (box 2) for the IE and OE to be calculated and, consequently, the energy balance (EB). The way of collecting the needed data (3) varied, because they could either be estimated (4) or obtained from field measurements (5).

The input energy - IE (11) is calculated by summing the results of $\mathrm{E}_{\mathrm{I}}(6), \mathrm{E}_{\mathrm{ED}}(7), \mathrm{E}_{\mathrm{W}}(8), \mathrm{E}_{\mathrm{IR}}(9)$ and $\mathrm{E}_{\mathrm{F}}$ (10), as shown in Equation 5.

The data concerning yield (12), dry matter content (13), crude protein (14), ether extract (15), crude

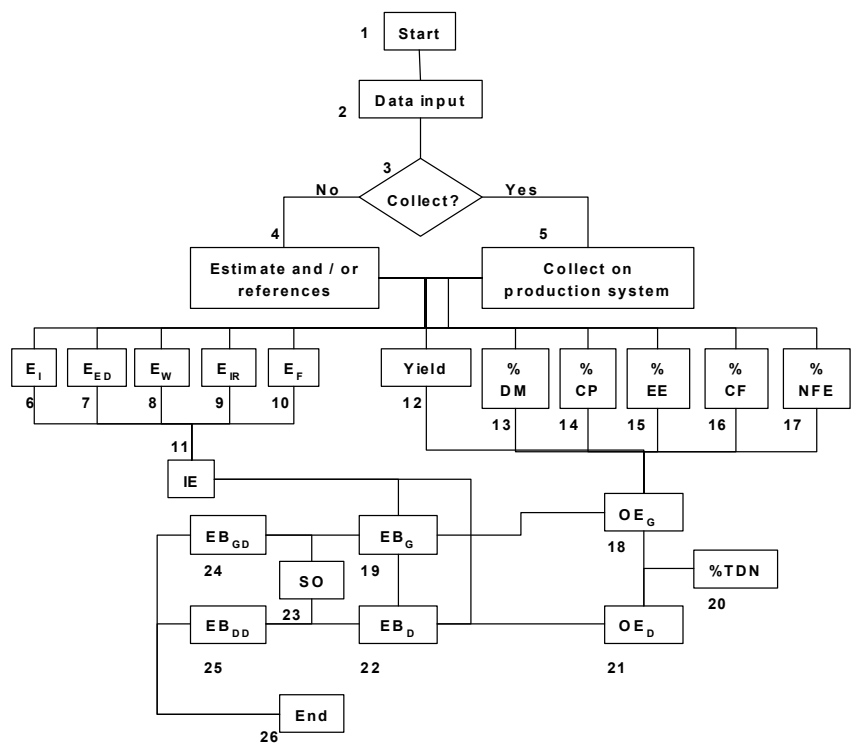

Figure 1 - General flow chart of the algorithm. 
fiber (16) and nitrogen free extract contents (17), allowed the determination of the total available energy $\mathrm{OE}_{\mathrm{G}}(18)$.

The gross energy balance (19) was determined from the IE and $\mathrm{OE}_{\mathrm{G}}$ data. To calculate the $\mathrm{OE}_{\mathrm{D}}(21)$, the TDN (20) was used as a factor of efficiency in offering energy to cattle, since it represented the effective availability of energy. Similar to the gross energy balance (19), the digestible energy balance was determined through a relationship between $\mathrm{OE}_{\mathrm{D}}$ and IE (11). The gross and digestible energy balances are divided by the soil occupation period (23) in order to determine the daily gross (24) and daily digestible (25) energy balances. The model supplies these four energy balance indexes, the demanded energy by each mechanical operation and the total demand of the production system. Through these data, distinct production systems can be compared.

The present model was used to evaluate two production systems: 1) maize silage, produced in Piracicaba, SP (22 $42^{\prime} 30^{\prime}$ 'S, $\left.47^{\circ} 38^{\prime} 00^{\prime} \mathrm{W}\right)$, and 2) Bermuda grass haylage, produced in Uberaba, MG (19 $56^{\prime} 45^{\prime \prime} \mathrm{S}$, $\left.48^{\circ} 02^{\prime} 15^{\prime \prime} \mathrm{W}\right)$. A sensitivity analysis was performed enabling the determination of the critical variables. The original value of each analyzed variable was increased $10 \%$, and the new energy balance obtained was compared to the original. Afterwards, the analyses of new scenarios were proposed to each production system.

\section{RESULTS AND DISCUSSION}

\section{Energy balance}

For the maize silage production system, IE was $18732 \mathrm{MJ} \mathrm{ha}^{-1}$, the $\mathrm{OE}_{\mathrm{G}} 282503 \mathrm{MJ} \mathrm{ha}^{-1}$, and $\mathrm{OE}_{\mathrm{D}} 189644$ $\mathrm{MJ} \mathrm{ha}^{-1}(\mathrm{TDN}=67 \%)$, therefore the $\mathrm{EB}_{\mathrm{G}}$ was 14.1 and the $\mathrm{EB}_{\mathrm{D}}$ 9.1. For the daily energy balances, gross $\left(\mathrm{EB}_{\mathrm{GD}}\right)$ and digestible $\left(\mathrm{EB}_{\mathrm{DD}}\right)$ were 0.087 and 0.057 per day, respectively. Regarding the effect of the mechanized agricultural operation on IE, fertilizers were responsible for $73.4 \%$ of the whole demand, due to the high level of enclosed energy in these industrialized inputs. This becomes the most important factor to be analyzed in order to increase the sustainability of the system.

The production of Bermuda grass haylage had a gross energy balance of -0.98 , consuming $198 \%$ of the $\mathrm{OE}_{\mathrm{G}}$ supplied by this system to the production of the crop. The IE of this system was $951,997 \mathrm{MJ} \mathrm{ha}^{-1}$, the $\mathrm{OE}_{\mathrm{G}}$ was $16,132 \mathrm{MJ} \mathrm{ha}^{-1}$ and the $\mathrm{OE}_{\mathrm{D}}$ was $9,870 \mathrm{MJ} \mathrm{ha}^{-1}(\mathrm{TDN}=$ $61 \%$ ), resulting in an $\mathrm{EB}_{\mathrm{D}}$ of -0.99 . The $\mathrm{EB}_{\mathrm{GD}}$ and $\mathrm{EB}_{\mathrm{DD}}$ were both -0.022 , because of the discrepancy between input and output energies.

Irrigation demanded a level of energy corresponding to $99.7 \%$ of the IE. The highest energy demanded in maize silage production was the fertilizer application and for the Bermuda grass haylage was the use of the irrigation system.

Sci. Agric. (Piracicaba, Braz.), v.62, n.1, p.1-7, Jan./Feb. 2005
Maize silage production system presented a positive energy balance (sustainable), unlike the Bermuda grass haylage. Although these results do not show evidence of sustainability when considering the energy availability, it must be emphasized that only one of the annual cycles of Bermuda grass was analyzed during winter time, when yield decreases and the need of irrigation increases. Data were collected in this way because it did not seem fair to present a mean energy balance, since summer and winter cycles have distinct duration. To determine the energy balance of other cycles, it is only necessary to adjust the data that really differ, like the use of irrigation. Fertilizer spreading, pesticide spraying, fuel consumption and machinery efficiency of the evaluated system are the same along the cycles.

Despite the worse performance in energy efficiency of the Bermuda grass haylage as compared to maize silage, it can be seen that energy is not the only imput of supplementary forage, since there are other nutritional components, such as protein. Bermuda grass haylage contained $15.1 \%$ of crude protein while maize silage contained only $5.1 \%$.

\section{Validation}

The results provided by the model for maize silage production are similar to data from previous studies (Figure 2). The validation of the Bermuda grass haylage data supplied by the model could not be made because there were no references on input and output energies for this sort of supplementary forage.

For maize silage, the results were compared to those of Phipps et al. (1976), Pimentel (1984), Hetz (1992) and Campos et al. (1998). Phipps et al. (1976) presented data for the conventional method (a), direct drilling (b) and the use of slurry (c) as fertilizer. Pimentel (1984) presented data in the USA, while Campos et al. (1998) presented for 14 crops grown in Brazil over 7 years.

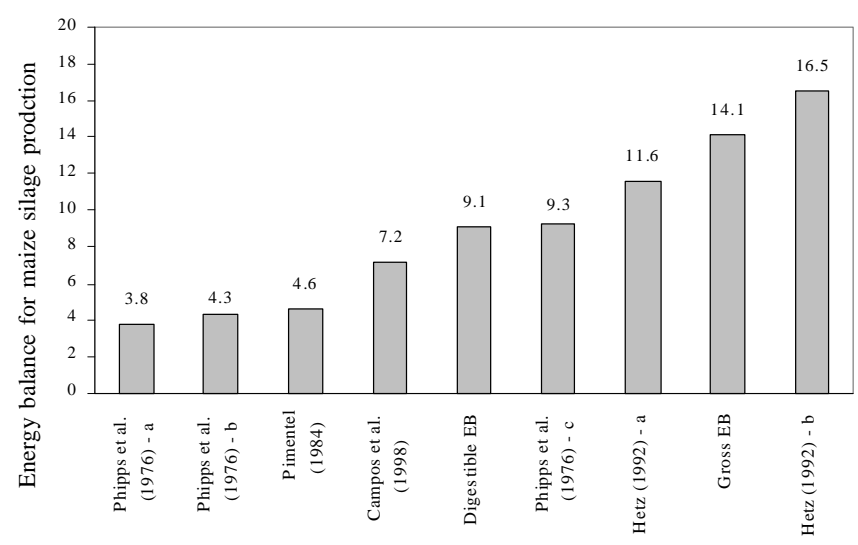

Figure 2 - Comparison of energy balance measurements for the maize silage production from different sources. 
Hetz (1992) determined the range of maize silage energy balances to be from 11.6 (a) to 16.5 (b) when analyzing 15 replications of areas smaller than 10 ha, and 9 larger than 10 ha, in Chile. All the original energy balance data were reduced to 1 unit of the original value since the way of determining the energy balance (output/ input) is different form that used in the present work (Equation 1).

\section{Sensitivity analysis}

The main factors of maize silage production that increase the gross energy balance, are those concerning the production results, qualitatively as well as quantitatively, such as yield, dry matter content, crude fiber content, and nitrogen free extract contents (Table $4)$.

As already shown, TDN content just affects the digestible energy balance. Soil occupation is the denominator of the daily rates $\left(\mathrm{EB}_{\mathrm{GD}} \mathrm{e} \mathrm{EB}_{\mathrm{DD}}\right.$ ) showing to be the most negative influence on both items when it is increased. Due to the high enclosed energy, fertilization appears to be the main constraint for the decreasing of gross and digestible energy balances. This fact occurs less with pesticides, since they are used in the diluted form, although they also present a high enclosed energy. The energy balance of production systems increased when the use of fertilizer decreased by $10 \%$, considering the same quality and quantity of production.

To understand this situation, some options can be made, such as decrease the use of fertilizers, use less concentrated types (e.g. increasing quality of mechanized operation, avoiding wastes etc.) or even organic fertilizers, alternatively. The sensitivity analysis did not find any alteration in Bermuda grass haylage production system, only because of the magnitude of the irrigation demand (Table 4). In maize silage production, the factors that had more positive influence in the energy balance were yield, dry matter and nitrogen free extract content.

\section{Scenarios}

The following scenarios were proposed for the maize silage: Scenario 1: original assumptions; Scenario 2: $10 \%$ decrease in the application of 20-00-20 fertilizer; Scenario 3: use of a 2-row harvester-chopper, keeping the same operational efficiency with $25 \%$ higher fuel consumption; Scenario 4: use of a less concentrated nitrogen fertilizer (15-05-10); Scenario 5: soil occupation for 120 days; Scenario 6: all events from Scenarios 2 to 5 occurring together (Table 5). In all simulations, yield, dry matter and TDN contents were considered the same as the original scenario.

The following scenarios were considered for Bermuda grass haylage: Scenario 1: original assumptions; Scenario 2: $30 \%$ decrease in yield, with no irrigation use; Scenario 3: crop cycle reduced from 45 to 41 days; Scenario 4: the events of scenarios 2 and 3 occurring together (Table 6).

For the maize silage crop, the scenario that presented the highest improvement $(13.3 \%)$ on the gross energy balance was the use of fertilizer with a lower concentration in nitrogen. This is due to the high enclosed energy in its manufacturing. In second place, $(8.9 \%)$ is the alternative of the 2-row harvester-chopper. Scenario 3 with the period of crop cycle reduced presented the highest improvement (34.5\%) for the daily gross energy balance for Bermuda grass haylage production. Scenario 2 provided the production system with the highest improvement (446\%) individually with a $30 \%$ decrease in yield because there was no use of irrigation. This significant improvement allowed the production system to become sustainable (positive). The worst data of the daily gross energy balance of Scenario 3 , when compared to the original, occurred because the same energy deficit was produced in a shorter period of time. The digestible and daily digestible energy balances were not evaluated by sensitivity analysis for both production systems because their analyses follow the trends of $\mathrm{EB}_{\mathrm{G}}$ and $\mathrm{EB}_{\mathrm{GD}}$, respectively, although considering the TDN content.

Table 4 - Sensitivity analysis of some factors on the energy balance.

\begin{tabular}{|c|c|c|c|c|}
\hline Items & $\mathrm{EB}_{\mathrm{G}}$ & $\mathrm{EB}_{\mathrm{D}}$ & $\mathrm{EB}_{\mathrm{GD}}$ & $\mathrm{EB}_{\mathrm{DD}}$ \\
\hline Fertilizer application rate at seeding & -2.13 & -2.19 & -1.15 & -3.51 \\
\hline Fertilizer application rate & -4.90 & -5.04 & -4.60 & -5.26 \\
\hline Yield & 10.72 & 11.18 & 11.49 & 10.53 \\
\hline Dry matter content & 10.72 & 11.18 & 11.49 & 10.53 \\
\hline Crude fiber content & 2.70 & 2.85 & 3.45 & 1.75 \\
\hline Nitrogen free extract content & 6.82 & 9.77 & 6.90 & 7.02 \\
\hline TDN content & - & 10.14 & - & 10.53 \\
\hline Soil occupation period & - & - & -8.05 & -8.77 \\
\hline
\end{tabular}

$\mathrm{EB}_{\mathrm{G}}$ : gross energy balance; $\mathrm{EB}_{\mathrm{D}}$ : digestible energy balance; $\mathrm{EB}_{\mathrm{GD}}$ : daily gross energy balance; $\mathrm{EB}_{\mathrm{DD}}$ : daily digestible energy balance 
Table 5 - Comparison of the new scenarios for maize silage.

\begin{tabular}{lccccc}
\hline Scenario & \multicolumn{2}{c}{$\mathrm{EB}_{\mathrm{G}}$} & & \multicolumn{2}{c}{$\mathrm{EB}_{\mathrm{GD}}$} \\
\cline { 2 - 3 } \cline { 5 - 6 } & Value & Change & & Value & Change \\
\hline 1 & 14.08 & 0.0 & & 0.087 & 0.0 \\
2 & 14.84 & 5.4 & & 0.092 & 5.7 \\
3 & 15.33 & 8.9 & & 0.095 & 9.2 \\
4 & 15.96 & 13.3 & & 0.099 & 13.8 \\
5 & 14.08 & 0.0 & & 0.117 & 34.5 \\
6 & 18.42 & 30.8 & & 0.154 & 77.0 \\
\hline
\end{tabular}

$\mathrm{EB}_{\mathrm{G}}$ : gross energy balance; $\mathrm{EB}_{\mathrm{GD}}$ : daily gross energy balance

Table 6 - Comparison of the new scenarios for Bermuda grass haylage.

\begin{tabular}{lrrrrr}
\hline Scenario & \multicolumn{2}{c}{$\mathrm{EB}_{\mathrm{G}}$} & & \multicolumn{2}{c}{$\mathrm{EB}_{\mathrm{GD}}$} \\
\cline { 2 - 3 } \cline { 5 - 5 } & Value & Change & & Value & Change \\
\hline & \multicolumn{3}{c}{$\%$} & & $\%$ \\
2 & -0.99 & 0.0 & & -0.022 & 0.0 \\
3 & 3.39 & 445.9 & & 0.075 & 440.9 \\
4 & -0.98 & 0.0 & & -0.024 & -9.1 \\
\hline
\end{tabular}

$\mathrm{EB}_{\mathrm{G}}$ : gross energy balance; $\mathrm{EB}_{\mathrm{GD}}$ : daily gross energy balance

\section{ACKNOWLEDGEMENT}

To FAPESP for the financial support of this work.

\section{REFERENCES}

CAMPOS, A.T. de; FERREIRA, W.A.; YAMAGUCHI, L.C.T.; RESENDE, H.; ALMEIDA, F.M. de. Balanço econômico e energético na produção de silagem de milho em sistema intensivo de produção de leite. Revista Engenharia Rural, v.9, p.1-20, 1998.
CRAMPTON, E.W.; HARRIS, L.E. Applied animal nutrition. 2.ed. San Francisco: Ed. Freeman, 1956.

FERRARO JR., L.A. Proposição de método de avaliação de sistemas de produção e de sustentabilidade. Piracicaba: USP/ESALQ, 1999. 132p. (Dissertação - Mestrado).

FLUCK, R.C.; BAIRD, C.D. Agricultural energetics. Gainesville: University of Florida, Agricultural Engineering Department, Institute of Food and Agricultural Sciences, 1982.197p.

FNP CONSULTORIA \& COMÉRCIO. Anualpec 2001: Anuário da Pecuária Brasileira. São Paulo, 2000. 359p.

HETZ, J.H. Energy utilization in chilean agriculture. Agricultural Mechanization in Asia, Africa and Latin America, v.23, p.52-56, 1992.

PELLIZZI, G. Use of energy and labour in Italian agriculture. Journal of Agricultural and Engineering Research, v.52, p.111-119, 1992.

PHIPPS, R.H.; PAIN, B.F.; MULVANY, P.M. A comparison of the energy output/input relationship for forage maize and grass leys on the dairy farm. Agriculture and Enviroment, v.3, p.15-20, 1976.

PIMENTEL, D. Handbook of energy utilization in agriculture. Boca Raton: CRC Press, 1980.

PIMENTEL, D. Energy flow in the food system. In: PIMENTEL, D.; HALL, C.W. (Ed.) Food and energy resources. Orlando: Academic Press, 1984 p.34-53.

SERRA, G.E.; HEEZEN, A.M.; MOREIRA, J.R.; GOLDEMBERG, J. Avaliação da energia investida na fase agrícola de algumas culturas. Brasília: Secretaria de Tecnologia Industrial, 1979. 86p.

STANHILL, G. Preface. In: STANHILL, G. (Ed.) Energy and agriculture. Berlin: Springer-Verlag, 1984. p.5-6. (Advances Series in Agricultural Sciences, 14)

ULBANERE, R.C.; FERREIRA, W.A. Análise do balanço energético para à produção de milho no Estado de São Paulo. Engenharia Agrícola, v.4, p.35-42, 1989.

Received August 08, 2003

Accepted October 08, 2004 